On Names in South Asia: Iteration, (Im)propriety and Dissimulation

\title{
Signboards and the Naming of Small Businesses: Personhood and Dissimulation in a Sri Lankan Market Town
}

Luke Alexander Heslop

\section{(2) OpenEdition}

\section{Journals}

Electronic version

URL: http://journals.openedition.org/samaj/4048

DOI: $10.4000 /$ samaj.4048

ISSN: 1960-6060

Publisher

Association pour la recherche sur l'Asie du Sud (ARAS)

Electronic reference

Luke Alexander Heslop, « Signboards and the Naming of Small Businesses: Personhood and

Dissimulation in a Sri Lankan Market Town », South Asia Multidisciplinary Academic Journal [Online],

12 | 2015, Online since 30 October 2015, connection on 20 April 2019. URL : http://

journals.openedition.org/samaj/4048; DOI : 10.4000/samaj.4048

This text was automatically generated on 20 April 2019.

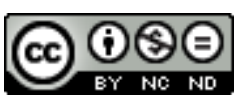

This work is licensed under a Creative Commons Attribution-NonCommercial-NoDerivatives 4.0 International License. 


\title{
Signboards and the Naming of Small Businesses: Personhood and Dissimulation in a Sri Lankan Market Town
}

\author{
Luke Alexander Heslop
}

\section{AUTHOR'S NOTE}

I would like to thank Veena Das and Jacob Copeman for inviting me to contribute something from Sri Lanka to this fascinating project. I am grateful for the comments and suggestions I received from the Centre for South Asian Studies at the University of Edinburgh, where I presented an early manifestation of this material in the faculty seminar. This paper has been much improved by generous comments from Garrett Field, Heid Jerstad, and Siobhan Magee. Asha Abeyasekera, Tudor Silva, and Dileepa Witharana helped me with a number of translations and caste-specific name interpretations. As ever, I am indebted to too many mudalalis to name.

1 'Gedara yana gaman! (On your way home!)' written in both Sinhala and English is the tagline on the signboard of the Cargill's Food City supermarket. The Cargill's franchise is ubiquitous across Sri Lanka, and with its outdoor parking spaces, staff uniforms, conveyer belt checkout, and conditioned air, the branch in the hot and dusty junction town of Dambulla quickly became popular, particularly among the town's aspiring middle class. Tacitly understood that 'On your way home' meant on your way home from work, the tagline on the signboard invites Cargill's customers in Dambulla to participate in a world of modern consumption somewhat disconnected from the design of local life. To pull into a modern supermarket on the drive home to get a few items, presumably in time for the evening meal, was an image that seemed incommensurate with what I had experienced to be the general run of events in everyday life in and around the town. People got fresh 
ingredients from local markets called polas, bought items such as soap, toothpaste, and shampoo from small shops called kadès, and arrived home-often from a long commute on the bus or short walk from the field-when the evening meal had long been prepared. ${ }^{1}$ Nevertheless, to live and shop the Cargill's way tapped into the aspirations of the middle class in the town.

2 The picture of modernity conjured by the single phrase, 'On your way home', was not lost on my friend Saman, who I joined in an internet café as two tech-savvy young men helped him make a new design with a similar tagline for the signboard above his own business, a bakery called 'Saman Bakers.' Saman conscripted me to help him with his signboard project. We grasped for words that might contain the same evocative fusion of home-food and a 'modern-lifestyle' captured neatly by Cargill's for his eponymous bakery, but failed. Nothing seemed to fit, and in the end 'Saman Bakers' was displayed sans tagline on the signboard.

While naming, branding and creating slogans are high-stakes matters for franchises and local businesses alike, my focus in this essay is to be found 20 minutes away from Cargill's Dambulla branch and 15 minutes from Saman Bakers, in Sri Lanka's largest wholesale vegetable market where similar issues of self-presentation play out. In the market, fixed above the opening of every stall, is a large colourful signboard that bears the name of the business beneath. Drawing on two years of ethnographic research, this essay examines the practice of naming small businesses in a market town in rural Sri Lanka, where I lived between 2010 and 2012 with a business family who owned a stall in the wholesale market. ${ }^{2}$ I went to the market almost every day to observe the vegetable business at the wholesale level and participate in market life. I conducted interviews and collected survey data in Sinhala. Vegetable merchants were often secretive and suspicious of outside interest in the inner workings of their businesses; introduction to the market through my host family was essential. Merchants' interest in who I was and the importance of having someone to vouch for me, coupled with guardedness regarding their own affairs, made the public projection of their professional-selves through signboards even more intriguing.

The question I pursue throughout is this: why do vegetable merchants give their businesses the names they do? Of the 144 signboards above the stalls in the wholesale market, 68 use a personal name; 26 use initials as business names; 22 use words of good will such as 'saralanka' (prosperous Lanka) and sandasaranaya (moon-blessed place); 19 stalls use place names or names of cooperatives and associations; whilst only nine stalls use surnames.

5 Signboards and the names they bear tell stories about the past and the future, success and shame, separation and loss, violence and dissimulation. While giving a name to a small business has an axiomatic instrumental property (identity and branding) by discussing naming practices against the backdrop of a more intimate set of criteria, such as intergenerational relationships, male sociality within business families, and the production of a new family through a new family business, much more can be read from the names that decorate signboards. Names given to small businesses evince a broader set of otherwise abstract social processes: the denigration of honorifics and patronymics, as well as anxiety manifest in the disconnect between what people want and what people perceive to be expected of them. 
6 Each optimistically selected business name, advertised on every carefully designed signboard, I argue, speaks to material and moral economies as well as nuanced perceptions of personhood. In this vein, the connection between the family name and the types of commodities these names become associated with is significant. What does it mean to connect the family name-which is expected to endure and grow-to a business that deals in short-term perishable items? A discussion of the commodity itself is consonant with Aditya Bharadwaj's discussion of the 'bad name' / badnam and the 'bad business' (this issue). I suggest that analysing 'good' and 'bad' names alongside 'good' or 'bad' businesses takes on renewed significance in the context of the 'family business,' where the stakes of bad branding seem particularly high and inescapably personal. With a focus on the small town merchant in South Asia, the themes of this paper resonate with the complex issues of branding and identity discussed by William Mazzarella (this issue). In the context of the small business, I suggest that selecting the name of the small business marks a separation intimately interwoven into the life courses of business families, akin to and often coeval with the production of a conjugal home. The more sinister side of naming draws attention to the navigation of identity markers that have assumed new significance throughout the war in Sri Lanka, notably ethnicity and religion; as well as the other less frequently documented marker of identity on the island that has existed relatively uninterrupted through times of conflict, namely caste. ${ }^{3}$

7 At the heart of this paper are the stories of logics that inform decisions made by vegetable merchants to name their businesses. By taking the signboards and the names of the businesses as the point of departure, I explore the problems of attributing one's name to a particular 'thing,' as well as attributing a product to a particular name. Such a discussion lends insight to the human world of the South Asian vegetable: a world in which an aubergine can leave a person morally compromised and socially stigmatised, or play a memorable role in an assassination.

\section{Establishing the market}

8 Sri Lanka's ongoing experiment with economic liberalisation, which began in the late 1970s, more or less maps onto its three decade long civil war (officially, 1983-2009). The area most significantly impacted by the policies of the open economy (the Sinhala dominated south), and those where its effects were largely absent (the Tamil dominated north and east), mirror the contours of the conflict itself. In the centre of this landscape, situated at a crossroads in the middle of the island, is the market town of Dambulla. Although situated further south from what became the much fought-over border areas, its population swell was part of the broader swath of formal and informal migration to the northern dry zone that accompanied state-led irrigation projects instigated in the late 1960s. Farmers and merchants moved in to cultivate or simply acquire land in the newly irrigated area. ${ }^{4}$

9 The increase in population, coupled with the new availability of lorries, transport vehicles, and credit, created business opportunities for rural entrepreneurs. With the arrival of mobile phones, which allowed businessmen to stay in contact with suppliers and buyers, conditions for middle-manning became even more advantageous, in particular for those in the centre of the island who could link up with consumers and suppliers from other towns. For entrepreneurs such as the Dambulla merchants in the wholesale market, the range of commercial activity was not limited to the local market, 
relationships with suppliers could be established with people all over the island. Many traders moved to Dambulla and maintained connections with the farmers in the area they moved from; these farmers would then provide the merchants with produce, which they would sell on for commission. For the market men, the spatial imaginaries of commerce and the networks of business extended beyond immediate interactions in the market. Buyers look for sellers as sellers look for buyers, and Dambulla merchants mediate this process. It is in the context of Dambulla as a town of newcomers and unknowns that establishing a name becomes particularly significant.

Before Dambulla came to prominence as a vegetable-trading town, the largest market for vegetables was the Pettah market in Colombo. If vegetables did not go to Pettah they were sold in small local markets called polas. ${ }^{5}$ According to Dambulla merchants, the largest trading point for vegetables in the centre of the island was at another junction town to the north of Dambulla, called Vavuniya. When the war in the north intensified in the late 1980s, the Vavuniya market ceased to be able to operate. As markets further north began to be controlled by the LTTE (Liberation Tigers of Tamil Eelam) or closed down entirely, Dambulla became the trading point that could service the north and the south. By the mid-1990s Dambulla-which had already been developing as an informal vegetable trading point-was the obvious choice for a more formalised central market that could feasibly reach the entire island. ${ }^{6}$ Today, Dambulla boasts the largest wholesale vegetable market on the island, mediating the sale of over 60 per cent of the island's vegetables. ${ }^{7}$

11 The wholesale vegetable market comprises 144 vegetable commission agent stalls, known as kadès. ${ }^{8}$ Each kade has a kadē team. Each team consists of a minimum of five people: the manager who is referred to as the mudalali (lit. money person), the accountant, the salesman, and three porters (referred to as nāthami, and occasionally as coolies). ${ }^{9}$ Each kade $\bar{e}$ in the market is exactly the same size as the next (approximately three meters by seven meters) and contains more or less the same equipment: a whiteboard, a set of weighing scales and a desk with a computer. Space in the kadē is left clear to store the vegetables in plastic woven sacks referred to as 'gunni-bags' or badu (things), and by some market men as simply kello (lit. the girls). ${ }^{10}$ There is a desk for the manager (henceforth mudalali) and the accountant that in almost all kadès runs parallel to the sidewall. Directly in front of the desk on the opposite side wall are two heavy-duty electric scales; the first set of scales is on the floor and weighs produce too heavy to be lifted to the second set, which is about shoulder height so porters who carry the produce in can roll it off their shoulders and on to the weighing platform.

The business of running a kade in the wholesale market is the business of being a commission agent. Commission agents lend money to farmers for the cultivation period; recipient farmers are then obliged to sell their produce through the stall or stalls belonging to the commission agents. A commission agent's interests lie in selling the highest volume of vegetables possible, as his commission is worked out by how much weight he can mediate the sale of through his stall. To be the biggest vegetable trader and turn over the highest volume of vegetables, a commission agent needs two things: farmers to bring stock and buyers to come and take it away. Maintaining buyers and sellers involves entering into relations of credit and debt in both directions: giving loans to farmers and advancing stock to buyers. Thus, being an adept creditor (in cash or kind) is crucial for building up one's name in the business and maintaining steady trade through the stall. One must build the name, and the name in turn will build the business. 


\section{The dubious morality of the (vegetable) trader}

13 At a retail level, vegetables can be sold by farmers looking to diversify their income, and by the poorest of people who will lay them out on the side of the street on top of old sacks. At the wholesale level, however, selling a vegetable requires connections and capital. Despite the capital and connections required, vegetable trading remains a problematic enterprise to cultivate status through. Partly because a vegetable is not a high-end or sophisticated good, but mainly because vegetable merchants are cursed by consumers when retail prices are high and cursed by farmers when wholesale prices are low. A vegetable is a commodity of considerable concern to a great many people: those who are not producing or selling, may well be buying, and those who are neither buying nor selling them, may well be eating them. Vegetables fuse and interrelate otherwise disparate social worlds. ${ }^{11}$ The material significance of vegetables in Sri Lanka, and their resonance in the public imagination, does not make them an easy commodity to cultivate a 'good name' through trading. In urban centres as well as the rural outskirts, bemoaning the high cost of a vegetable is commonplace and the retail cost of vegetables is a subject of widespread concern, if not suspicion. In his ethnography of the advertising industry in Sri Lanka, Buying and Believing, Steven Kemper goes so far as to suggest that 'most Sri Lankans have had suspicions at one time or another [of being cheated] for fruits, vegetables, rice, or any commodity that needs to be weighed' (Kemper 2001: 188). The cost of a vegetable is not merely a discursive yardstick with which to measure the state of the national economy, but also a moral commentary on the state of society. When vegetables were overproduced, it was often attributed to youth unemployment: the idea being that because young people had nothing else to do they would cultivate some vegetables for money. Wasteful gluts, as well as shortages in supply that lead to high prices, are understood by many as connoting the government's inability to control manipulative middlemen and harness the malevolence of the open market.

Selling vegetables on such a scale at the wholesale market is perhaps indicative of a transformation in agricultural production away from production for use, toward production for the market-a type of production anathema to the Sinhala nationalist conception of the idyllic peasant life, in which the rural cultivator is assumed to live a life of subsistence production organised around Buddhism, paddy fields and the tank that irrigates them (Moore 1985: 190). It is in this context that the growth of the market sits uncomfortably for influential characters such as the chief priest of the local Buddhist Temple. Animosity from the priest in Dambulla toward the work of supposedly usurious and immoral middle-men in the vegetable trade was set against the backdrop of the otherwise morally virtuous work of wet-rice paddy cultivation, a notion inspired in no small part by the colonial predilection for such orderly and visible organisation of labour (Spencer 2003: 37), and more recently, the increasing influence of merchants in local level politics (see Heslop 2014)..$^{12}$

15 Vegetable merchants themselves are well aware of public accounts of their business operations as exploitative and parasitic, since this view is one regularly expounded in the national press..$^{13}$ That Sri Lankan vegetables travel too far from field to plate, and that producers and consumers are out of pocket because there are too many exploitative middlemen in the system, were themes that consistently emerged in interviews with economists and agro-economists. In this light the naming of a vegetable stall could be 
understood as strategic, reactionary, even defensive. Consider the upbeat and patriotic tone of stalls such as, jayalanka-victorious Lanka, jayabima-victorious land, saralankaprosperous Lanka, āsiri-good wishes, ${ }^{14}$ sithumina-thoughtful, sandasarnaya-moonblessed place, Mahajana-public, and, vimukthi-liberation.

So what we have with the vegetable is a fairly unappealing commodity. A thing that almost everybody has an opinion of-a vegetable doesn't particularly allow for specialist knowledge: a carrot is by and large a carrot. It's a commodity of relatively unexciting, vapid, and obvious utility, a material of low value which offers little by way of status for the salesman through its handling. In fact, what small profit margins there are in the vegetable business render the vendor vulnerable to accusations of manipulation and exploitation. Portrayal of the wholesale traders, collectively named middlemen ( atharamediyen), as usurious, corrupting, and detrimental to the vegetable industry is a common feature in the literature on the agricultural economy in Sri Lanka (Esham \& Usani 2006; De Silva, Ratnadiwakara \& Soysa 2008; Perera, Kodithuwakku \& Weerahewa 2004). This representation is juxtaposed to that of the seemingly virtuous cultivator and the mechanisms of the state that toil to support the agricultural industry in post-colonial Lanka.

17 The name given to the traders inside the wholesale market, mudalali, is itself indicative of the vilification of the trader. In Sinhalese the word mudalali is used to refer to a shopkeeper or a trader and is ubiquitous throughout the island. Mudalali literally means 'money person.' It implies 'making a living by buying and selling' (Weeratunge 2010: 339). ${ }^{15}$ In rural circles mudalalis were often seen as morally dubious (SouthwoldLlewellyn 1994; Weeratunge 2010). This was largely based on the idea that mudalalis were often considered as 'outsiders.' Stereotypically, mudalalis would have been Tamils, Muslims, or low-country Sinhalese, who would have moved from 'outside' to a particular area, often, but certainly not exclusively, to do business. Therefore, while the name mudalali is a superficial indicator of occupation it also constitutes a set of ideas about place and belonging.

That merchant capitalists were commonly 'outsiders' to a community is part of a 'history of otherness' (Weeratunge 2010:333) which it has been argued characterises the development of capitalism in Sri Lanka (Moore 1997) and elsewhere (Simmel 1990; Chirot \& Reid 1997; Hart \& Hann 2009). According to Hart and Hann (2009), mercantile activities have been historically restricted to excluded or minority ethnic groups. This, they claim, was a 'ploy' by rulers to deal with the dangers that markets presented, 'ensuring no citizens had access to money and that those who did lacked political power,' the most poignant example of this perhaps being 'the pariah status of Jews in medieval Europe' (Hann \& Hart 2005: 2). Anthony Reid and Daniel Chirot describe entrepreneurial minorities as 'essential outsiders' (1997), and draw comparisons between the 'creative and vulnerable roles' of Jews in central Europe and Chinese in Southeast Asia as, “'outsiders at the center" of dynamic processes of change' (Reid 1997: 33-4). In South Asia, merchants and traders have been depicted as having an ambiguous relationship with the nation-state, they often came from different places, spoke different languages, and followed different religions; such qualities fuzzy the desired coherence of the nationstate's image of itself (Reid 1997: 33). ${ }^{16}$ The Marwaris of India might also be added to this list of mercantile-outsiders. Within the Marwaris, as Chris Gregory points out, adherents of Jainism-a religion that 'has its origins in anti-Brahmin protest' (Gregory 1997: 166) are the 'undisputed mercantile elite.' In Sri Lanka, even a name as general as that for 
merchant, mudalali, positions its bearer in relation to the nation-state, or in relation to the nation-state's ideal image of itself, in a particular way. In the case of Sri Lanka this is an image largely dominated by romanticised ideals of subsistence paddy farmers, government schoolteachers, and more recently, soldiers. If the characteristics of being a morally dubious 'outsider' are conferred through being a merchant, in Sri Lanka it is particularly problematic when the word 'merchant' is prefixed by the word 'vegetable.'

\section{To put the vegetable trade to your name}

In 1998, traders who had previously been selling vegetables in small shops sprawled around the crossroads in the centre of the town were moved into the stalls at the new wholesale market. Most of the stall owners had previously sold vegetables from the junction in the 1970s. By 2011, when the vegetable stalls had been operating there for some time, many of the kadès were no longer managed by the original trader who founded the business at the junction, but rather by their sons or nephews. Sons and nephews, who take over the management of the stalls in their late twenties and early thirties, usually keep their father's name as the name of the kadès, or the same name as the business that operated from the junction. ${ }^{17}$ This was professed at times to be for reasons of sentiment, in honour of the father who founded the business, but more often it was claimed to be because it is their fathers-and not the sons and nephews-with whom the farmers are familiar. Many of the first generation of vegetable merchants came from farming backgrounds themselves. Keeping the name of the original founder of the business on the signboard above the door enabled the farmers to locate and patronise the stall and the trader with whom they had already established a connection. However, this was not the only strategy employed to build a recognisable brand for their business, nor was it the only logic at work in designing the advertisement boards that hang above each of the kadès.

Many of the kadès were named after the son who is expected to inherit the business. This was the case for Saman, with whom this essay began, whose first name prefixed all of the businesses owned by the family. The reason for this, as it was explained to me by his father, was simply because Saman was his only son and he expected him to take over all of the businesses. Here, names compel succession. A similar story was told by the founding fathers of 'Thushara Traders' and 'Buddhika Stores' and there are many more kades in the market named after the sons of the original owners who are expected to inherit them.

21 Significant in the use of the son's first name rather than the family name on signboards of the market kadēs is that it-unlike the family name-does not indicate caste. In her ethnography of the European fur trade, Siobhan Magee (2013) asserts that the type of 'thing' a business trades plays a role in informing the decision to introduce the family name to the enterprise. For traders at the Copenhagen Fur Auction, family names 'indicated who the "big players" were' and 'whose fur animals had the "best pedigree" (Magee 2013: 231). In a similar way, talk of 'pedigree,' heritage, family, and family names proves particularly well suited to the sale of animals and animal products, as Rebecca Cassidy demonstrates in her work on the breeding and marketing of thoroughbred race horses in Newmarket (Cassidy 2002). For well-established Allepan suq traders described by Annika Rabo, the family name assures a reputation among traders (Rabo 2005). According to Paul Anderson, the trading names of 'old money' families of the Allepo suqs 
that have been built up over generations are asserted as a 'form of distinction' in the face of 'new' petit bourgeois traders who have come to prominence through recent liberalisation (Anderson 2011: 42). In these markets, the family name matters. In contrast to these examples in which the family name plays a central role in trader selfpresentation, within the wholesale market only nine family names are printed on the signboards of the 144 kadess, whilst personal names feature on 68 signboards. A preoccupation with 'heritage' is seemingly less significant for vegetable merchants and there may be several reasons for this.

Unlike Polish fur, fine Syrian fabrics and thoroughbred race horses, luxurious items that evoke in their transactors a sense of high-quality and refinement (in product and production) over time, vegetables are quotidian items and imbue little status or heritage onto the family name of the trader. At the point of wholesale in the vegetable trade, the quality of the 'thing' is measured in touch, texture, and the likelihood of it surviving a bumpy journey to the next market. While some vegetables are more popular than others or thought to be more 'up market,' there is little space for discernment or taste that could be attributed to the family name at this point in a vegetable's 'social life' (Appadurai 1986). In contrast to fur and high-quality fabric, vegetables are goods that perish relatively quickly, it may be considered inauspicious to put the family namewhich is expected to endure and grow-to a business that deals in short-term perishable items.

23 Not connecting the vegetable business with the family name might be suggestive of a sense of shame associated with vegetables and the relatively low cultural status attached to the vegetable trade itself. Unflattering depictions of vegetable merchants more generally as usurious and morally dubious may similarly dis-incentivise the putting of family names to vegetable businesses. Alternatively, as the following section will explore, family names can be omitted from the vegetable trade because the family name is itself indicative of something the trader may wish to conceal or distance from the business: 'lower' caste status, which is also discussed in terms of ancestry and 'pedigree,' or perceived lack thereof (Abeyasekera 2013: 209), or some other potentially dangerous signifier of identity such as religion or ethnicity.

\section{To put the family name to the business}

Names as personal markers of identity have an historic basis in caste (Amarasiri 2009: 78), whilst caste has a basis in work and livelihood, or, duty and obligation to a King. In Sri Lanka, much like in India, caste is hierarchical; names indicative of caste therefore also have the potential to be hierarchical. ${ }^{18}$ Sinhala names can connote caste, the village a person is from, their occupation, religion and ancestry. At the same time, names can be changed; therefore a name can equally disguise hierarchical connotations. There is considerable resistance to open discussion of caste in Sri Lanka (Stirrat 1982, Spencer 1990; Abeyasekera 2013), as in India where caste has been described as an embarrassment for nationalist projects of $20^{\text {th }}$ century modernity (Dirks 2001). ${ }^{19} \mathrm{~A}$ consistent trait among many of the middle-class business families I knew in Dambulla, was a pronounced reluctance to attribute any significance to the role of caste in their daily lives. ${ }^{20}$

A complex and not entirely consistent discussion regarding Sinhala family names and their significance in the social organisation of rural life in Sri Lanka peaked in the middle 
of the twentieth century. ${ }^{21}$ To pick up the story on names and naming practices in 2015, without getting tangled in the details, two key points about Sinhala names need to be understood. Firstly, family names in Sri Lanka, passed down through men from one generation to the next, carry with them recognisable status markers of a caste and class nexus. Secondly, names can and often are changed.

One way of changing one's name is through marriage, preferably hypergamy. Drawing on the work of Kumari Jayawardena (2007) and Michael Roberts (1997), Asha Abeyasekera notes that 'from the early $20^{\text {th }}$ century onwards marriage became a principal strategy for social mobility for both men and women within the newly formed bourgeoisie' (Abeyasekera 2013:102). Yalman claims that a hypergamous marriage can facilitate a domino-effect of name changes outwith the married couple and into the wider kin network whereby those who want to lay a claim-through the marriage-to the "higher status' name simply just take the new name on (Yalman 1967). Another way to change one's name is to do it officially.

Amarasiri De Silva (2009) analyses the various trends in name changing practices in the late $20^{\text {th }}$ century using announcements of name changes in the national newspapers. The abridged version of Amarasiri's conclusion is simply that nobody changes their name to resemble a name that is considered 'lower' than the one they already have. ${ }^{22}$ Those who are not the dominant goyigama caste either become goyigama or choose names that do not reveal caste at all (acaste names). Or they change their names to resemble those of the dominant caste of the area in which they live. In any case, the name they have chosen is a name that is considered either 'higher' status than the one they have, or a name that does not convey caste status at all. An overwhelming number, however, opt for goyigama names. Those who are goyigama and change their name tend to do so in order to move up in the hierarchy of goyigama names-normally into the radala name group, the aristocratic sub-caste of the goyigama.

Amarasiri's conclusion that people generally appropriate a name considered higher status than the name they currently have, although remarkable in its detail, is not particularly new. In the 1960s Gananath Obeyesekere remarked on the wide use of patronymics among affluent families in the Kandyan provinces. The 'usurpation' (and pejoration) of such titles began apace during the colonial era after the ban on assuming patronymics and titles was lifted (Obeyesekere 1967: 225). Ralph Pieris, in Sinhalese Social Organisation (1956), explains that 'Scions of a man honoured with the Patabendi (an honorific conferred by a king) title 'Suriyasekera Mudiyanse' would convert it into a patronymic by adding the suffix 'lage' (belonging to or descending from) and call themselves Suriyasekera Mudiyanselage, "descendants from Suriyasekera Mudiyanse" (Pieris 1956: 173; cf. Obeyesekere 1967: 224). In southern Sri Lanka, the Portuguese period (1505-1658) was particularly important in terms of name changing, 'for it allowed lower castes who dared not usurp patabendi titles an opportunity to take over Portuguese "surnames"' (Obeyesekere 1967: 225). ${ }^{23}$ Although caste cannot be transgressed-it is only superficially changed by the change in title-caste can, has, and is dissimulated and even emulated by changing one's name.

The dissimulation of caste becomes significant in the context of Dambulla, as many vegetable mudalalis who have become successful, and wish to be highly regarded locally, are not from the most highly regarded caste, goyigama. However, the nine kadès that do have family names on the signboards above the businesses either do not reveal caste at all (acaste names) or are recognisably goyigama. One in particular is from the high-status 
radala name group, whilst another has added to the family name on the signboard a highstatus honorific not present in the family name as written in the ownership documents. For most merchants, caste was ardently dismissed as antiquated and unnecessary as a form of status distinction. Occupation and the associated resources and influence it afforded, as well as money and material assets, were thought to be much more important components of attaining high status than caste. Attaining status requires attributing value to its production within one's lifetime through work, becoming rich, and transcending the cultural and material conditions one was born in to. This requires a 'strategic de-linking' (Abeyasekera 2013: 202) of prestige and status from 'a good birth' and resituating it in more immediate contexts. An important part of a project like this is to dissimulate caste.

As well as being a cursory signifier of caste, which in turn acts as a marker of place, lineage and 'pedigree' (Abeyasekera 2013: 290), and by extension status, surnames or family names are also explicitly indicative of race and ethnicity. This was something else that mudalalis have an interest in dissimulating or subtly playing down where possible in the market. Of the twelve stalls operated by Muslims in the market, none have recognisably Muslim names on the signboards. Muslims trade under signboards that display an acronym, a Sinhala name, the name of a gem, or something vaguely patriotic such as 'Lanka.'

31 There was once a Tamil man with a license to trade from a wholesale kadè . Thought to be an LTTE informer, with a network of spies in the market working as wage labourers, after a bomb went off on a bus in the centre of the town in 2008 he was promptly assassinated inside his vegetable stall. Two men supposedly from a Government Special Task Force (STF) were said to have gone into the vegetable stall, inquired about the price of an aubergine, shot him dead instantly when he answered, and sped away on a motorcycle. There is perhaps no redemptive business name or carefully selected signboard tagline that could have saved the murdered trader once his assassination had been sanctioned. However, the murder of the Tamil trader illuminates the importance of names in the market place, since the potential for 'dangerous' people to be absorbed into the marketto work and be accommodated unregistered, unknown and unnamed-subsequently developed into an acute matter of concern for the traders and the market authorities alike. A system of registration for all informal labourers was promptly implemented and nobody could henceforth work in the market without registering their name on their National Identity Card (NIC). This programme of making labourers visible through their names spoke to fears about front-line deserters from the Government forces, as well as Tamil Tiger cadres, concealing themselves within the market. ${ }^{24}$

With the exception of the assassinated Tamil stall owner and a handful of Muslims, all the kade owners are Sinhala. None of the kades owned by Muslims use their names on the signboards, many keep the Sinhala name of the original owner of the stall, or an initial, like 'C. S Stores' and 'S. L. Stores.' Two Muslim-owned stalls that have been renamed are called 'Ruby Traders' and 'Lanka Stores.' Muslim traders mainly deal with import items such as potatoes and onions, but some deal with dried fish products that come from the east coast. Dealing with products such as dried fish, although officially permissible in the perishables market, angered many Sinhala traders who thought it inappropriate. In 2012, the Dambulla mosque, attended by Muslim market traders, was attacked by a group of protestors roused by the chief priest of the Dambulla Temple. The attack stood out as a significant event against the backdrop of island-wide anti-Muslim sentiment from 
Buddhists in Sri Lanka that has intensified since the end of the war (Heslop 2014: 21). It is in this context that the names of Muslim market stalls might need to be disguised. Although entirely possible to find out which kades in the market are run by Muslims, to exclude a Muslim name from the signboard and trade under an acronym, a Sinhala name, or something vaguely patriotic like 'Lanka,' reflects a kind of subtle yet significant everyday-type gesture of minority politics learned over decades of ethnically and racially driven conflict (Hannifa 2007; Thiranagama 2012).

\section{In your own name}

At one level, what names and family names on signboards reveal can be understood in terms of caste, ethnicity, and religion, but an interpretation closer to home could see signboards reflect the aspirations and ambitions between generations of trading families. A more intimate reading of the decisions that inform the naming practices of a business draws attention to the complex relationships between fathers and sons, in particular between influential land owning fathers and sons living in patrilocal conjugal residence. Scholarship on male intergenerational relations in rural Sri Lanka points out that a man who remains in his natal village after marrying a woman from a distant village cannot easily cultivate the fields belonging to his father in-law and is thus dependent on his own father for land to work (Tambiah 1965, see also Yalman 1967). Therefore, sons who remain in their parental home remain under the rule of their fathers. Saman is one such verilocal son, heir to several enterprises and destined to work under the watchful eye of his father.

Saman is a popular name in Dambulla. It is the name of a famous deity in the Buddhist pantheon who guards Sri Pāda, a pilgrimage site on top of Samanalaya Mountain (butterfly mountain), where Sinhala Buddhists maintain there exists a footprint made by Lord Buddha 'during his third mythical visit to the island' (Premakumara De Silva 2013: 159). ${ }^{25}$ Saman also means 'the rising morning sun,' a name particularly apposite for a bakery that opens early and faces due east. Saman's name was written on the signboards that hung above the various enterprises owned by his father: 'Saman Bakers,' 'Saman Traders,' 'Saman Stores,' and 'Saman Mill.' The only business that did not bear his name was the sari shop started by his sister. Despite the fact that his name prefixed almost all of the family businesses, Saman will not be the sole beneficiary of the businesses. Saman will inherit the parental home (maha gedara), but will receive only one third of the businesses and land. Saman's two sisters will inherit the remaining two thirds of their father's business assets. Patrilineal succession in Sri Lanka is undermined by a system of bilateral inheritance, in which all siblings have equal rights to their parents' legacy; thus Saman's hold on the family businesses existed only superficially on the signboard itself.

Before taking over the vegetable stall and becoming a commission agent Saman had to work every day in the family bake house with his brothers-in-law. Although from a merchant family and not interested in farming paddy fields, Saman is similarly dependent on his father for land, work, capital and connections. Despite the fact his father named almost all of his businesses after him, Saman knew that his two sisters would equally inherit the business assets. The matter of equal inheritance with his sisters, despite the businesses being 'in his name,' was not an issue for Saman; the frustrations he 
felt stemmed from having to work under his controlling father and alongside his sister's husbands.

A critical reading of the power discourses behind a name, such as Susan Benson's discussion on injurious names and the strictures imposed by names in the context of slavery (2006), draws attention to the potentially significant omission of a possessive apostrophe; it is 'Saman Bakery' and 'Saman Mill,' and not 'Saman's Bakery' or 'Saman's Mill. ${ }^{26}$ Saman's father, as the giver of the name to the business, has control over the business that bears the name Saman. In a similar vein, Saman's father also named his son Saman and exercises control over him. In particular, over his son's access to the business that bears his name; the business through which Saman can, in a sense, build or take ownership of his own name. Benson's assertion that 'names are never simply our own: they are conferred on us' (Benson 206: 179) and that, 'We are named by others and, in many naming systems, for others: in a critical sense, then, names belong as much, if not more, to the givers of names as to those that bear them' (Benson 2006: 180) accords strikingly with my own interpretation of Saman's relationship with his father. Here, his personal name is not only under the control of his father, but is overshadowed by the incorporation of wider family. ${ }^{27}$

The omission of the family name takes on a new significance when analysing Saman's signboard from the perspective of a young man attempting to disconnect himself (where beneficial) from the family he was born into, when trying to become successful in the world of work. At the bake house his father owned, the sense of independence, ownership and separation from his parental family that may otherwise have come with the business name 'Saman Bakers' was undermined by the fact he had to work under his father's supervision and with his brother-in-laws. The bake house was a family business associated with wider kin-in-laws, lineage, and the family he was born into-whereas the vegetable kade è represented a break in the lineage, and Saman's role as head of 'his' business and provider for his own nuclear family. Although it was his father who named the various businesses using Saman's first name, it should not distract from how important it is for Saman to work under his own name in the market, as opposed to his family name; or, in the market on his own as opposed to in the bake house with his sisters' husbands.

A trader such as Saman, who would otherwise draw on the social capital that belonging to a known family permits, would not be able to hide his family name from anyoneregardless of what he called his kade e. Nevertheless, there is a propensity for new businessmen to name their kades in homage to their new families and not their old ones. While the bake house is more evocative of a typical 'family business,' the vegetable kadē is an asset of a business family: normally an asset that is destined for a son, and often a wayward son, as a means for him to break away from the family he was born into and provide for the one he is the head of.

Despite the trajectory of the business down the male line, there are no stalls in the market which postfix the family name with, '...and Sons,' a formula which has been adopted by other businesses in Sri Lanka such as Jinadasa and Sons, Samuel and Sons, and most famously, Perera and Sons. Since the vegetable market is a predominantly male dominated space, one might expect the names of the stalls to reflect a desire for male succession. ${ }^{28}$ Surprisingly however, many of the market kadēs are named after the traders' wives, daughters and nieces. Naming the kade $\bar{e}$ after wives and daughters is not about expressing intent for succession, or to build the name of the daughter as a known person 
in the town, but rather a form of mapping business providence onto other types of success in more intimate and domestic spheres of life such as marriage and childbirth. Rupasinha, the owner of a kadè called 'Sudu Nadi Traders,' told me how 'Sudu Nadi' was a combination of the names of his wife, his son, and his daughter. Standing under the signboard of his vegetable store one evening, Rupasinha explained that: good for business. If the child is good for business then it is fortunate if you name your business after the child.

Figure 1 : Rupasinha's store

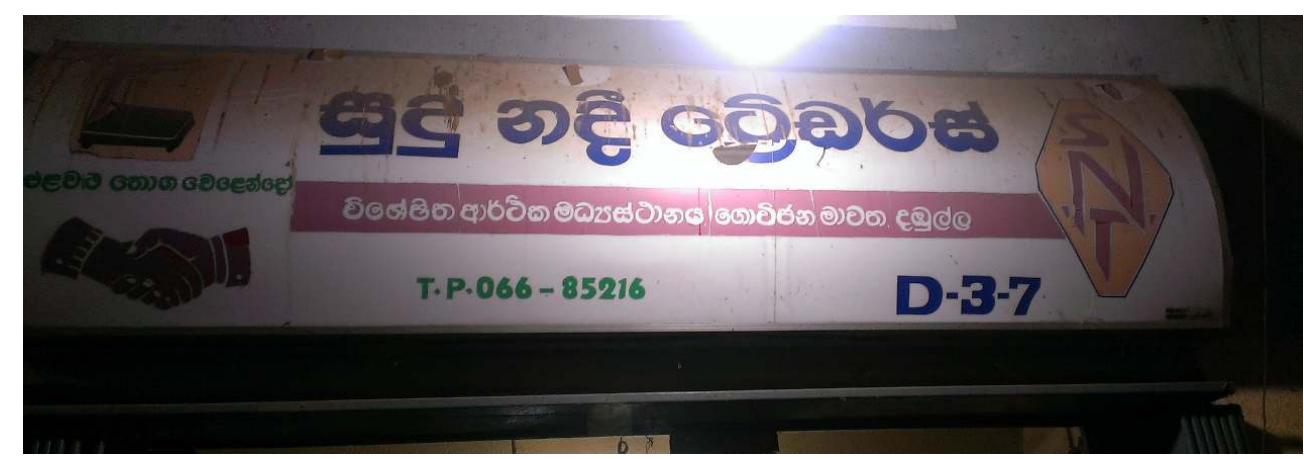

'SUDU NADI TRADERS'

41 I went to meet Rupasinha having been told that he had a particularly striking success story. Rupasinha is now a wealthy businessman who, as well as owning the vegetable business in the market, owns a restaurant in the town and a successful real-estate business. Rupasinha's pre-marital poverty formed the backdrop for his narrative. In the 1970s, he explained, he was a wage labourer and drove a tractor for a landowner near Kegalle for Rs.30 per day. After he married, his fortune (suddenly) changed. He moved to Dambulla to start selling other people's vegetables for a commission and subsequently earned himself a stall in the wholesale market in the late 1990s, where his fortune further developed. Uplifting as Rupasinha's success story was, it was not particularly novel. Many of the people from rural areas around Dambulla who became traders in the 1970s to mid-1980s had a similar 'rags-to-riches' story to tell. Ratna Mudalali, the president of the influential Market Traders' Union, and incidentally one of the richest men in Dambulla, delighted in telling me that when he came to Dambulla he did not even have ten rupees in his pocket and came to work selling lottery tickets by a small shack to people travelling through. When I moved to Dambulla at the beginning of 2011, Ratna Mudalali was the most powerful trader in the market and his son was a candidate in the mayoral election.

In Dambulla, 'origin stories' (Yanagisako 2002) do not run particularly deep. Young merchants like Saman and his friends were born in Dambulla, and their fathers had already established businesses and acquired land in the town. It was generally the case that their fathers were the founders and expectations to continue the businesses were on them. In Saman's case it was his grandparents that moved to Dambulla. Moreover, it was his grandmother (father's mother) who obtained valuable pieces of land in and around the town through a connection with the local monk. His grandfather died when his father was young and it was up to Saman's father to develop the businesses on the land. Saman's origin story, and the worries his father had about him taking ownership, fit the adage that recurred through Yangisako's fieldwork among silk industry capitalists: 'The 
Grandfather founded (the firm), the sons develop it, and the grandsons destroy it' (Yanagisako 2002:175). Among Dambulla vegetable traders more generally however, origin success stories and anxieties about the destruction of the business were for the most part contained within two generations. Parents often told me how they were building something that their children would most likely throw away. Few kadès had pictures of the fathers who founded the business on the wall, since pictures of parents are usually displayed after death and many of the original owners were still alive. ${ }^{29}$

The only picture that consistently featured on the walls of the kadès, that wasn't of a deity, was of the local minister, Janaka Bandara Tennekoon. His picture was displayed in every stall, as he was the man who issued the licenses to trade from them. In the picture, his image was pasted into the centre of the frame against a white background that gave the impression that he was floating like a deity. This god-like image of the minister served as a good reminder of his ultimate ownership and the name that really mattered in the context of the market.

'Ramya Traders' is owned by a merchant known fondly as Podi Māma (small uncle). Podi Māma has the worn and weathered look of a farmer-cum-trader, or worker-cum-owner, and does business in a loose fitting shirt and sarong, his chunky and rough digits garnished with an enormous sovereign ring. Podi Māma's appearance fits the iconic image of the rural merchant conjured in the stereotypes espoused by my friends in the capital. It was not just the Colombo middle class quick to categorise Dambulla merchants as distinctly 'new-money'; the traders themselves were aware that Dambulla is a town where people have 'got rich quick.' Recognition that people's social, cultural and economic possibilities had broadened somewhat rapidly was conveyed through the local idiom, kathusage kara ratrang benda wage (lit. like a lizard wearing a gold chain), a phrase that was used to suggest that somebody was presenting an image of themselves that did not fit who they 'really' were.

Podi māma's elder brother owns two of the largest and most popular clothes shops in the town, both named Ramya Textiles, which are named after his daughter, Ramya. Podi Māma was the first to obtain the market stall and decided to name it after his elder brother's daughter since the name was already an established brand name in the town (apparently for thirty or so years). When his elder brother also got a kadē in the market, next door to Ramya Traders, he had to choose a different name. The elder brother's stall, which he named Jayanthi Traders is run by his son Chaminda. 'Jayanthi,' another woman's name, was chosen because the first letter ('Ja') had been deemed by an astrologer to be a letter that would bring prosperity to the business. Podi Māma's brother, like many other traders, chose to make the 'lucky name' of the store the name of a woman. 
Figure 2: The sign for Ramya Traders

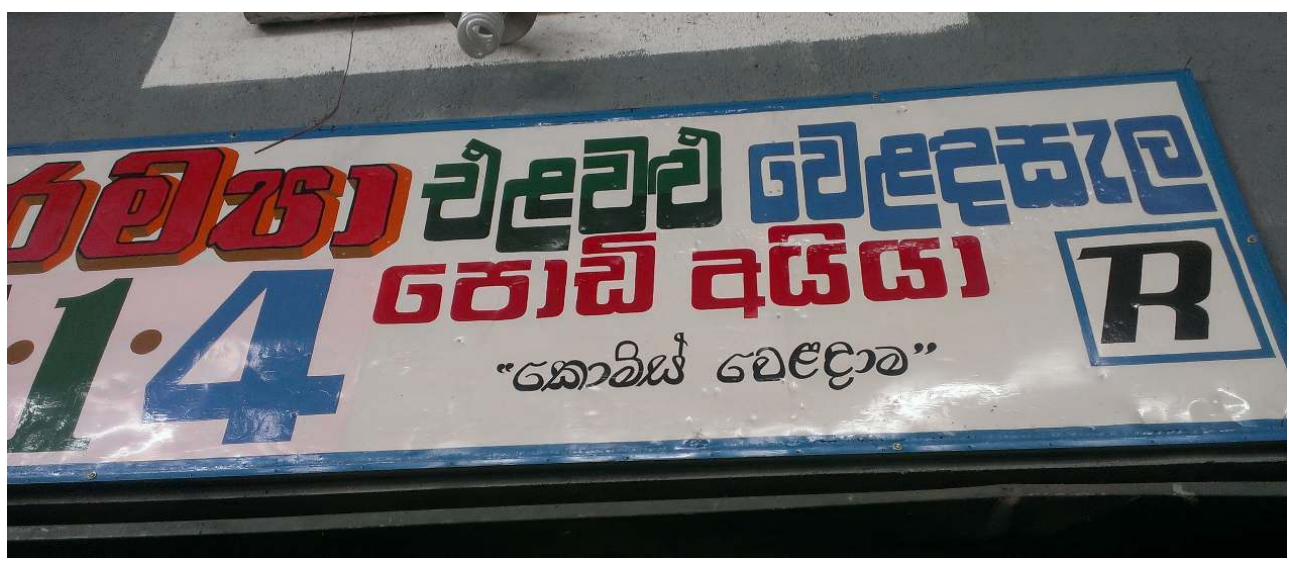

THE SIgN READS: RAMYA Vegetable tRADER: LITTLE ELDER BROTHER. 'COMMISSION TRADER'

Figure 3: The sign for 'Jayanthi Stores'

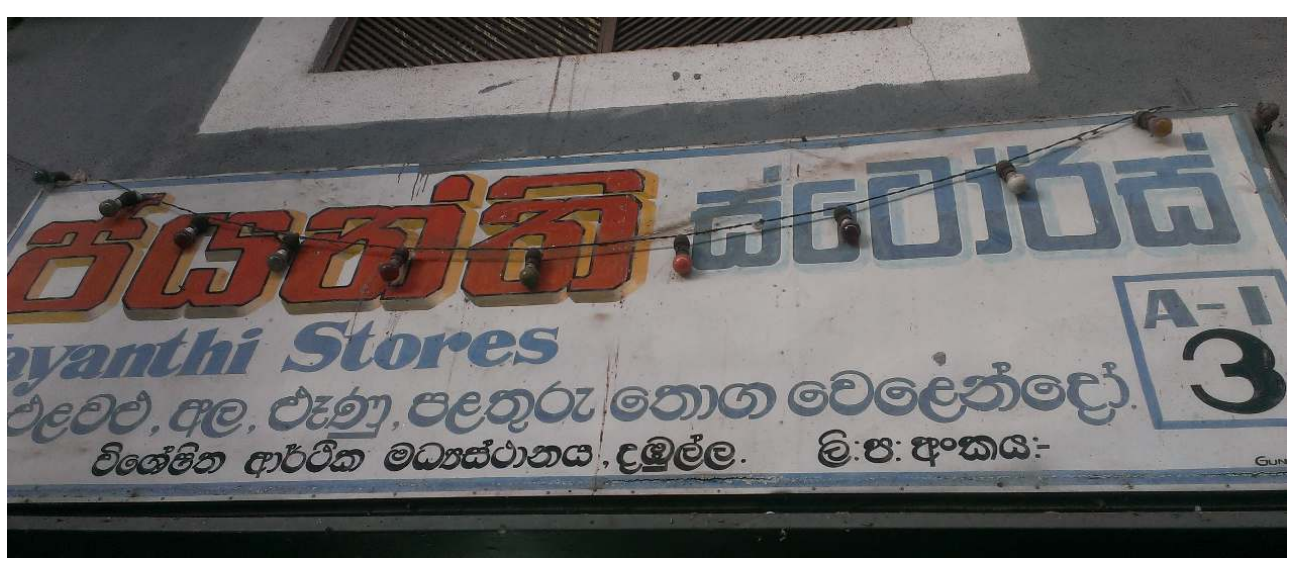

'Lucky names' (wāsanāwa nama) are lucky because the initial letter has been deemed to be so by an astrologer. In some instances a monk will give the lucky letter. In other cases the kades are named after children who, by virtue of their birth, are thought to bring good fortune to the business. The children will also have been given their names following the advice of an astrologer. It is not unusual for merchants to be told by astrologers specifically whether or not a particular child will be good for business. If they are not, then it is unlikely that their name will make it on to the billboard of the business. Wickrama and Hansani Traders, combines the 'lucky name' of the daughter (Hansani), and the known name of the father (Wickrama), with whom the farmers who sell their produce through the store are familiar. Wickrama's son did not make it onto the signboard as it was deemed that his name was not as 'lucky' as the daughter's. Male names that are chosen from an auspicious letter may not have anything to do with a male relative connected to the founder at all; Vimukthi (lit. liberation) and Laxman-which presumably connects directly to Laxmi, the goddess of wealth-are popular male names considered to be 'lucky' by the merchants. ${ }^{30}$ 


\section{On your way home}

Beginning with Saman's admiration of the local branch of the national supermarket franchise Cargill's, who, with a cunningly deployed slogan on a signboard proved effective 'middlemen to the national imagination' by marketing an intelligible-if impracticable-vision of modern consumption (Kemper 2001: 6 cf. Mazzarella 2003) this essay moved to examine the imaginative signboards of the nation's middlemen. In the simplest terms, the names on the kade signboards are about being known. They are not advertisements in the sense that they might attract new customers. They are a means through which mudalalis portray themselves-for the most part-to one another. Whilst businesses in Sri Lanka are often named after people, this essay has explored the stories and logics behind why particular businesses are given personal names rather than surnames. In the context of the vegetable market I explored the implications of connecting ones family name to the ill-reputed vegetable trade, and, conversely, the implications of attaching the 'wrong' kind of name to a business at all.

At one level I examined why merchants map family names onto business in some instances and not others. Of further interest however, was which family it was that made it onto the business signboard. In the case of Saman, the business name was entwined in a struggle with his father and in-laws over the management of a business that was in his name. Invariably, in the market it was the names connected with the 'new family,' as in the wife, son or daughter of a conjugal pair, and not the 'old family' as evoked through alliance and descent and encapsulated through the use of the family surname, that would feature on the signboard. As we saw with Rupasinghe and Saman, and as was the case for many vegetable mudalalis, selecting the name of the small business marks a separation intimately interwoven into the life courses of business families, often even coeval with the production of a conjugal home. A discussion of names that compel succession and influence futures has led to a discussion of 'origin stories.' Behind the stories of names and origins is a lesser discussed aspect of traders' lives: that they selectively view their family members as instrumental in their changing fortunes and map life events such as marriage and childbirth on to the success of their business ventures.

\section{BIBLIOGRAPHY}

Abeyasekera, Asha (2013) The Choosing Person: Marriage, Middle-Class Identities, And Modernity in Contemporary Sri Lanka, PhD dissertation, University of Bath.

Abeysekara, Ananda (2002) Colors of the Robe: Religion, Identity, and Difference, Colombia (South Carolina): University of South Carolina Press.

Alexander, Paul (1979) “"Malu Mudalali” Monopsonies in Southern Sri Lankan fish trading', Social Analysis, 2, pp. 3-17. 
Anderson, Paul (2011) Threads of Virtue: The Ethical Lives of Syrian Textile Traders, PhD dissertation, University of Edinburgh.

Appadurai, Arjun (1986) The Social Life of Things: Commodities in Cultural Perspective. Cambridge [Cambridgeshire]: Cambridge University Press.

Benson, Susan (2006) 'Injurious Names: Naming, Disavowal, and Recuperation in Contexts of Slavery and Emancipation', in Gabriele Vom Bruck \& Barbara Bodenhorn (eds.), The Anthropology of Names and Naming, Cambridge: Cambridge University Press, pp. 178-200.

Carter, Charles (1924) A Sinhalese-English dictionary, Colombo: ‘Ceylon Observer' printing works.

Cassidy, Rebecca (2002) The Sport of Kings: Kinship, Class, and Thoroughbred Breeding in Newmarket, Cambridge: Cambridge University Press.

Chirot, Daniel; Reid, Anthony (1997) Essential Outsiders: Chinese and Jews in the Modern Transformation of Southeast Asia and Central Europe, Seattle: University of Washington Press.

De Silva, Amarasiri (2009) 'Name Changing, Caste and Personal Identity Complex Among the Sinhalese in Sri Lanka', The Sri Lanka Journal of Humanities, 35(1\&2), pp. 76-98.

De Silva, Premakumara (2013) 'Reordering of Postcolonial Sri Pāda Temple in Sri Lanka: Buddhism, State and Nationalism', History and Sociology of South Asia, 7(22), pp. 155-76.

De Silva, Harsha; Ratnadiwakara, Dimuthu; Soysa, Shamistra (2008) ‘Transactional Costs in Agriculture: From the Planting Decision to Selling at the Wholesale Market: A Case-Study on the Feeder area of the Dambulla Dedicated Economic Centre in Sri Lanka', URL: http:// www.cprsouth.org/wp-content/uploads/2010/03/Dimuthu-Ratnadiwakara.pdf [accessed 5 August 2014].

Dirks, Nicholas B. (2001) Castes of Mind: Colonialism and the Making of Modern India. Princeton (New Jersey): Princeton University Press.

Esham, M.; Usami, K. (2006) 'Procurement Behaviour of the Fruit and Vegetable Industry in Sri Lanka', The Journal of Agricultural Sciences, 2(3), pp. 36-44.

Gregory, Chris A. (1997) Savage Money: The Anthropology and Politics of Commodity Exchange, Amsterdam: Harwood Academic.

Haniffa, Farzana (2007) 'Muslims in Sri Lanka's Ethnic Conflict', Polity: A Journal for Peace, Democracy and Pluralism, 4(2), pp. 16-18.

Hann, Chris. M.; Hart, Keith (2009) Market and Society: The Great Transformation Today, Cambridge: Cambridge University Press.

Heslop, Luke A. (2014) ‘On Sacred Ground: The Political Performance of Religious Responsibility', Contemporary South Asia, 22(1), pp. 21-36.

Heslop, Luke A. (2015) The Making of the Merchant Middle Class in Sri Lanka: A Small Town Ethnography , PhD dissertation, University of Edinburgh.

Hughes, Dhana. (2013) Violence, Torture, and Memory in Sri Lanka: Life after terror, London \& New York: Routledge.

Jayawardena, Kumari (2007) Nobodies to Somebodies: The rise of the Colonial Bourgeoisie in Sri Lanka, Colombo: Social Scientists' Association \& Sanjiva Books.

Kemper, Steven (2001) Buying and Believing: Sri Lankan Advertising and Consumers in a Transnational World, Chicago: University of Chicago Press. 
Leach, Edmund R. (1960) ‘The Sinhalese of the Dry Zone of Northern Ceylon', in George Peter Murdoch (ed.), Social Structure in Southeast Asia, Chicago: Quadrangle Books.

Leach, Edmund R. (1961) Pul Eliya, a Village in Ceylon: A Study of Land Tenure and Kinship, Cambridge: Cambridge University Press.

Magee, Siobhan (2013) An Ethnographic Account of Fur in Generation, Class, and Inheritance in Krakow, Poland, PhD dissertation, University of Edinburgh.

Mazzarella, William (2003) Shoveling Smoke: Advertising and Globalization in Contemporary India, Durham: Duke University Press.

Moore, Mic (1985) The State and Peasant Politics in Sri Lanka, London: Cambridge University Press.

Moore, Mic (1990) 'The ideological History of the Sri Lankan Peasantry', Modern Asian Studies, 23 (1) pp. 179-207.

Moore, Mic (1997) 'The Identity of Capitalists and the Legitimacy of Capitalism: Sri Lanka since Independence', Development and Change, 28(2), pp. 331-66.

Obeyesekere, Gananath (1967) Land Tenure in Village Ceylon: A Sociological and Historical Study, London: Cambridge University Press.

Obeyesekere, Gananath (1975) ‘Sinhalese-Buddhist Identity in Ceylon', in George DeVos \& Lola Romanucci-Ross (eds.), Ethnic Identity: Cultural Continuities and Change, Palo Alto (California): Mayfield Pub. Co., pp. 231-58.

Obeyesekere, Gananath (1981) Medusa's Hair: An Essay on Personal Symbols and Religious Experience, Chicago: University of Chicago Press.

Peebles, Patrick (1990) 'Colonization and Ethnic Conflict in the Dry Zone of Sri Lanka', Journal of South Asian Studies, 49(1), pp .30-55.

Peiris, Ralph (1956) Sinhalese Social Organization: The Kandyan Period, Colombo: Ceylon University Press.

Perera, M; Kodithuwakku, S.S.; Weerahewa, J. (2004) 'Analysis of Vegetable Supply Chains of Supermarkets in Sri Lanka', Sri Lankan Journal of Agricultural Economics, 6(1), pp. 67-81.

Pinney, Chris (2013). Artisan Camera: Studio Photography from Central India, Chennai, India Tara Books.

Rabo, Anika (2005) A Shop of One's Own: Independence and Reputation among Traders in Aleppo, London: I.B. Tauris.

Roberts, M. (1982) Caste Conflict and Elite Formation: The Rise of the Karava Elite in Sri Lanka, 1500-1931, Cambridge: Cambridge University Press.

Roberts, M. (1997) 'Elite Formation and Elites, 1832-1931', Sri Lanka: Collective Identities Revisited, 1, [Colombo]: Marga Institute, pp. 191-265.

Silva, Kalinga Tudor; Sivapragasam, P. P.; Thanges, Paramsothy (2009) Casteless or Caste-Blind? Dynamics of Concealed Caste Discrimination, Social Exclusion, and Protest in Sri Lanka, Copenhagen: International Dalit Solidarity Network.

Simmel, George (1990 [1978]), The Philosophy of Money, London: Routledge \& Kegan Paul.

Southwold-Llewellyn, Sarah (1994) 'The Creation of an Outsiders' Myth: A Case Study from Sri Lanka', in Hans-Dieter Evers \& Heiko Schraders (eds.), The Moral Economy of Trade: Ethnicity and Developing Markets, London: Routledge. 
Spencer, Jonathan (1990) A Sinhala Village in a Time of Trouble: Politics and Change in Rural Sri Lanka, Delhi: Oxford University Press.

Spencer, Jonathan (2003) 'A Nation "Living in Different Places": Notes on the Impossible Work of Purification in Postcolonial Sri Lanka', Contributions to Indian Sociology, 37(1\&2) pp. 25-47.

Stirrat, R.L (1982). 'Caste Conundrums: Views of Caste in a Sinhalese Catholic Village', in D. B. McGilvray (ed.), Caste Ideology and Interaction, Cambridge: Cambridge University Press.

Tambiah, S. J. (1965) 'Kinship Fact and Fiction in Relation to the Kandyan Sinhalese', Journal of the Royal Anthropological Institute of Great Britain and Ireland, 95(2), 131-73.

Thiranagama, Sharika (2011) In My Mother's House: Civil War in Sri Lanka, Philadelphia: University of Pennsylvania Press.

Thiranagama, Sharika (2012) 'Muslims, Ethnicity and Minority Identity in Sri Lanka', in Christophe Jaffrelot \& Aminah Mohammad Arif (ed.), Politics and Religion in South Asia: Wither Secularism?, 'Purushartha' series, 30, Paris: Editions de l'EHESS.

Van Daele, Wim (2013) 'Igniting Food Assemblages in Sri Lanka: Ritual Cooking to Regenerate the World and Interrelations', Contributions to Indian Sociology, 47(1), pp. 33-60.

Weeratunge, Nireka (2010) 'Being Sadharana: Talking about the Just Business Person in Sri Lanka', In, M. Lambek (ed.), Ordinary Ethics: Anthropology, Language, and Action, New York: Fordham University Press, pp. 328-48.

Winslow Jackson, Deborah (1977) 'Polas in Central Sri Lanka: Some Preliminary Remarks on the Development and Functioning of Periodic Markets', in S.W.R. de A. Samarasinghe (ed.), Agriculture in the Peasant Sector of Sri Lanka, Colombo: Wesley Press, pp. 56-84.

Yalman, Nur (1960) ‘The Flexibility of Caste Principles in a Kandyan Community’, in, E.R. Leach (ed.), Aspects of Caste in South India, Ceylon, and Northwest Pakistan, Cambridge Papers in Social Anthropology, Cambridge.

Yalman, Nur (1962) 'The Structure of the Sinhalese Kindred: A Re-Examination of the Dravidian Terminology', American Anthropologist, 64, pp. 548-75.

Yalman, Nur (1967) Under the Bo Tree: Studies in Caste, Kinship, and Marriage in the Interior of Ceylon, Berkeley: University of California Press.

Yanagisako, Sylvia Junko (2002) Producing Culture and Capital: Family Firms in Italy, Princeton: Princeton University Press.

\section{NOTES}

1. I use the English plural marker 's' to pluralise some Sinhala words rather than directly transliterate these from the Sinhala plural forms, e.g. 'Pola' becomes 'Polas' 'kadē becomes 'kadès and 'mudalali' becomes 'mudalalis.'

2. The research was funded by The Economic and Social Research Council (ESRC).

3. A notable exception was the attempt made by the LTTE to 'ban caste' in the areas they controlled throughout the war (see Thiranagama 2011), and the involvement of 'lower caste' young men in the southern insurgencies of 1971 and 1989 (Hughes 2013; Silva, Thanges and Sivapragasam 2009).

4. Those who moved into the newly-irrigated areas-predominantly Sinhala Buddhist men-were encouraged to do so as part of a broader ethno-nationalist project that framed the state-led resettlement projects in terms of resettling an ancient Sinhala kingdom that thrived in the Dry 
Zone a millennium ago (Moore 1985). This narrative was said to have been built upon a mythologised history created by nineteenth century Sinhalese elites (Peebles 1990: 31) who traced the ancestry to North Indian settlers of 'Aryan' stock (Obeyesekere 1975; cf. Peebles 1990: 31).

5. For more on Sri Lankan polas and periodic markets, see Deborah Winslow's excellent work (Winslow 1977).

6. The Dambulla Dedicated Economic Centre is the largest market of its kind and reportedly receives around 26,500 metric tons of vegetables per week, approximately 3.7 million kilograms per day. It is also the most centrally located to service the island's vegetable needs and for many years was the only market of its kind. Up to 1200 lorries can go through the DDEC in one day (De Silva, Ratnadiwakara \& Soysa 2008: 4).

7. http://www.trade.gov.lk/web/ [accessed 20 April 2014]

8. The term kade is used as shorthand for any kind of shop.

9. Occasionally porters will refer to themselves as nathāmi, but this and the term 'coolie', or in Sinhala' kuli väda, which means wage labourer, held derogatory connotations. I will use the English word porter throughout.

10. 'Badu' being referred to as 'kello' in the market is an inversion of the way 'kello' are derogatorily referred to as 'badu' outside of the market.

11. In much the same way Wim Van Daele has discussed the preparation of food, and in particular the use of coconuts in Sri Lanka (Van Daele 2013).

12. Campaigns for rural regeneration documented by Moore in the mid-1980s encapsulated this with the slogan, wewa, chaithiya, yaya'-'(irrigation) tank, temple, paddy field' (Moore 1985: 190).

13. Whilst mudalalis are commonly castigated in the national press, in Dambulla feelings towards mudalalis can be ambivalent. Successful mudalalis were also secretly and openly admired.

14. Obeyesekere (1981: 203) translates āsiri from Sanskrit as, 'the fulfillment of a benediction.'

15. Carter's Dictionary (1924: 503) interprets mudalali as 'capitalist, proprietor, chief man' (see also Southwold-Llewellyn 1994: 196).

16. Also see Jonathan Spencer (2003).

17. See Christopher Pinney, who has also documented this to be the case in photography businesses in small towns in India (Pinney 2013).

18. Unlike in India however, it is not understood in terms of blood or considered in terms of purity and pollution.

19. Caste has not been a census category since 1871 (Silva, Thanges \& Sivapragasam 2009: 1)

20. When the Dambulla Temple began to undertake its own ordinations it somewhat controversially initiated a policy of non-caste based ordinations (Abeysekera 2002: 174).

21. These discussions coalesced around themes such as Ge names, glossed as a 'house name' that refers more specifically to what Tambiah refers to as a 'corporate family group' (Tambiah 1965), a married couple living outside the parental home; patabendi patronymics, a type of honorific supposedly conferred by a king (Pieris 1956: 173); and Vasagama honorifics, a prefix to a name, which according to Obeyesekere (1967) creates a surname that denotes where somebody is from and their sub-caste. For readers with the inclination I suggest these names, Edmund Leach (1960, 1961), Nur Yalman $(1960,1962,1967)$, S.J. Tambiah $(1964,1968)$, Gananath Obeyesekere (1967).

22. Goyigama is generally considered to be the highest status caste group in the Sinhala caste system. Goyigama is also the majority caste in Sri Lanka. Goyigama is generally thought of as a caste of cultivators, however, not all who cultivate in Sri Lanka are goyigama, nor do all goyigama necessarily cultivate

23. Obeyesekere claims here that the names, Perera, De Silva, De Mel and Salgado were most popular among Karawe and Salägama castes (Obeyesekere 1967; cf. Roberts 1982). Salägama, a caste commonly associated with cinnamon peeling. Karawe, a caste typically associated with fishing (see Alexander 1979). 
24. I was told that, fearing the vegetable market might become a target, the Traders Union made an unsuccessful request to have all lorries checked for bombs as they entered the market.

25. Tamil Hindus claim it is the footprint of Lord Siva (Sivan-oli-padam). On the contrary, Muslims and Christians maintain that it belongs to Adam (Baba Adamalei). Premakumara De Silva argues that the site has been, 'reordered into an ethnic majoritarian Buddhist space in the context of the rise of Sinhala Buddhist nationalism in post-colonial Sri Lanka' (Premakumara De Silva 2013: 159).

26. However, this is more than likely a matter of broken English.

27. In addition to the element of control, naming the store 'Saman' is simultaneously a mark of his father's sentiment and affection.

28. It is not merely a general expectation that men should be involved in the vegetable business, the licenses to run vegetables stalls in the DDEC are passed on to the sons of the owners. While sons and daughters ordinarily have equal rights when it comes to inheriting their father's assets (bilateral inheritance) it is patrilineal succession that is written in to the legal management of the kades themselves; if the owner is not present in the kade then, officially, the only person who can take his place is his son.

29. One trader, Jayatissa, died during my fieldwork and when his son took over the vegetable stall he put a big picture of his father on the wall behind the desk.

30. People called Laxman are often given the nickname 'Lucky.'

\section{ABSTRACTS}

This paper concerns the naming of stalls in Sri Lanka's largest wholesale vegetable market. Each optimistically selected business name, advertised on every carefully designed signboard, I argue, speaks to material and moral economies as well as nuanced perceptions of personhood. Signboards and the names they bear tell stories about the past and the future, success and shame, separation and loss, violence and dissimulation. In the context of the small business, I suggest selecting the name of the small business marks a separation intimately interwoven into the life courses of business families. The more sinister side of naming draws attention to the navigation of identity markers that have assumed new significance throughout the war in Sri Lanka, notably ethnicity and religion; as well as other less frequently documented markers of identity on the island that have existed relatively uninterrupted through times of conflict, namely caste.

\section{INDEX}

Keywords: Sri Lanka, merchants, signboards, vegetables, kinship

\section{AUTHOR}

\section{LUKE ALEXANDER HESLOP}

Postdoctoral Research Fellow, Social Anthropology, University of Edinburgh 